The Discovery of the Very Important Lundai Sin, or Swat River Author(s): H. G. Raverty

Source: The Geographical Journal, Vol. 8, No. 5 (Nov., 1896), pp. 525-526

Published by: geographicalj

Stable URL: http://www.jstor.org/stable/1774094

Accessed: 27-06-2016 07:50 UTC

Your use of the JSTOR archive indicates your acceptance of the Terms \& Conditions of Use, available at

http://about.jstor.org/terms

JSTOR is a not-for-profit service that helps scholars, researchers, and students discover, use, and build upon a wide range of content in a trusted digital archive. We use information technology and tools to increase productivity and facilitate new forms of scholarship. For more information about JSTOR, please contact support@jstor.org.

The Royal Geographical Society (with the Institute of British Geographers), Wiley are collaborating with JSTOR to digitize, preserve and extend access to The Geographical Journal 
unfairly long communication I cannot ask for the space that would be requisite if I were to state the grounds of my new conclusion, which must await some other time and some different channel of publication, but I shall be happy to submit them privately to Colonel Holdich if he would care to know them. He would, I feel sure, be satisfied with them.

To put the result summarily, Fahraj near Bampur is the place locally called Fahra in the middle ages. Then the Basurjan of Ibnu Khurdadhbeh, the Masurjan of Idrisi, and the Masakan of Istakhri, are one and the same place. This, in all probability, occupied the site of the present Sarbaz. It is stated to have been 24 farsakhs from Fahra, while Sarbaz (according to Sir F. Goldsmid's route) is 73 miles distant from that place. In Ibnu Khurdadhbeh's time it was the chief town of "the Schismatics" (for his Medinetu' $l$ Kharun read Medinetu' $l$ Khuruj), and these people, we know from the later Arab writers, were settled along the course of the Sarbaz river. Subsequently Rask became their capital. This place, lower down the river and 40 miles from Sarbaz, is not mentioned by Ibnu Khurdadhbeh, but I would identify it with his "village of Yahya bin Amr," 10 farsakhs from Basurjan (Sarbaz), and would suppose that Yahya was then the headman of the place, or that he was, perhaps, its founder. From Rask onwards to Panjgur, I must confess I can make nothing of the route, nor can I identify a single one of the ten intervening stations. According to the later Arab geographers, there was a route from Rask through the present Bampusht district to Dizak, and thence to Panjgur, the entire distance from the first place to the last being 6 stages, while modern itineraries and maps would make it about 230 miles. How, then, can we account for Ibnu Khurdadhbeh's 93 farsakhs, or say 336 miles-perhaps 370 miles? The route cannot have proceeded from Rask through the Kej valley, otherwise Kej, the capital and probably the most ancient place in the valley, would surely have appeared among the stations; but it does not, nor does any other place east or west of Kej shown in published maps. There I must leave the difficulty. Perbaps Colonel Holdich, with the far greater advantages he possesses, can solve it. Allowing it its full weight, it does not, in my opinion, counterbalance the evidence in favour of the identifications above stated, though in present circumstances I can only offer these for provisional acceptance.

M. R. HAIG.

\section{The Discovery of the very Important Lundai Sin, or Swat River.}

October 12, 1896.

In the Geographical Journal for this present month there is a letter on the subject of "Makran," by Lieut.-Colonel Holdich, R.E., on which subject I have nothing to say at present; but, in the last paragraph of the letter, referring to the serious mistakes made with respect to that part of the Kafiristan, which has caused some trouble, and more discussion, he says, "We found that the river flowing through Kafiristan from the west into the Chitral or Kumar [sic] river, and correctly called Arnawai, ... was also called 'Bashgol' and 'Lundai Sin ;'" and that he has "discovered one other very important Lundai Sin, which is also called the Swat river."

It is to this last "discovery" I have more particularly to refer. Any small or minor river may be, and is, called Landaey Sin-not "Lundai"-by the Afghan people and others dwelling near them. Land is the Pushto adjective for "small," "little," "short," etc., and the diminutive form of that adjective is landaey for the masculine singular, landa'i for the feminine, and landi for the plural, both masculine and feminine. Sin, or Sind, a corruption of Sanskrit sindhu, means a

No. V.-November, 1896.]

$2 \mathrm{~N}$ 
sea or river; consequently any small river would be called the Landaey Sin without that being the proper designation of such river.

As to the discovery that the "very important Lundai Sin is called the Swat river," it is a great mistake. The river of Panj-korah and the river of Suwat, or Suwad, having united, join the river of Kabul and its tributaries at Do-bandí, a little to the north of the village of Shaikh Isma'il, and is ther known as the Landaey Sin, or Small or Little river, until north of Atak it unites with the Aba Sin, or Father River, or Father of Rivers, the name by which the Sindhu or Indus is known in those parts by the inharitants generally. The Landaey Sin is also shown in the map of the "Mullah's Explorations" in 1876.

A person cannot stay long at Peshawar or in its district without soon knowing what Landaey Sin refers to; and in "An Account of the Province of Pesháwar" which I submitted to Government in 1851, for which I received the thanks of the Government of India, and which was subsequently published in the Transactions of the Bombay Geographical Society in 1852, I described the Landaey Sin. In my Pushto Dictionary, published in 1860, the Landaey Sin will be found described at pp. 636 and 877, in my "Account of Upper and Lower Suwát to the source of the Suwát river," in the Journal of the Asiatic Society of Bengal for 1862, and also in my 'Notes on Afghanistan,' etc., pp. 215 and 243, and other places ; and by the name of Landaey Sin the united rivers have been known "from time immemorial."

\section{H. G. Raverty, Major, Bombay Army (Retired).}

\section{GEOGRAPHICAL LITERATURE OF THE MONTH.}

\section{Additions to the Library.}

By HUGH ROBERT MILL, D.Sc., Librarian, R.G.S.

THE following abbreviations of nouns and the adjectives derived from them are employed to indicate the source of articles from other publications. Geographical names are in each case written in full:-

A. = Academy, Academie, Akademie.

Ann. = Annals, Annales, Annalen.

B. = Bulletin, Bollettino, Boletim.

Com. = Commerce, Commercial.

C. Rd. $=$ Comptes Rendus.

Erdk. = Erdkunde.

G. = Geography, Geographie, Geografia.

Ges. = Gesellschaft.

I. = Institute, Institution.

J. = Journal.

M. = Mitteilungen.

On account of the ambiguity of the words octavo, quarto, etc., the size of books in the list below is denoted by the length and breadth of the cover in inches to the nearest half-inch. The size of the Journal is $10 \times 6 \frac{1}{2}$.

\section{EUROPE.}

Austria-Alpine Provinces. M.G. Ges. Wien. 39 (1896): 529-540.

Richter.

Ueber einen historischen Atlas der österreichischen Alpenländer. Von E. Richter.

On a projected historical atlas of the Austro-Hungarian monarchy, with suggestions for such a work dealing in detail with the alpine provinces. The paper is reprinted from a memorial volume to Prof. Franz von Krones of Graz, only fifty copies of which appeared.

Austria-Bosnia and Herzegovina. Globus 70 (1896): 165-170; 184-190. Hoarnes.

Bosnien und die Hercegovina in Vergangenheit und Gegenwart. Von Dr. Moriz

Hoernes. With Illustrations. 